\title{
Insidence of Superficial Mycotic Infections in Surguja, Chhattisgarh
}

\author{
Ashok K. Shukla \\ Department of Microbiology, Holy Cross Women's College, Ambikapur (CG), India
}

\begin{abstract}
A mycological study was undertaken to determine the prevalence and incidence of superficial mycotic infections in Surguja, Chhattisgarh. Out of 187 cases 64 cases (45.3\%) were infected with dermatophytes. Among them the commonest etiological agent encountered was Trichophyton rubrum (28.1\%) followed by Trichophyton mentagrophytes (9.3\%), Trichophyton tonsurans (4.7\%) and Trichophyton violaceum (3.1\%). Other most frequently isolated non-dermatophytes were Candida albicans (34.3\%) and Aspergillus species $(20.3 \%)$ respectively.
\end{abstract}

Keywords: superficial mycotic infections, Trichophyton rubrum, Chhattisgarh

\section{Introduction}

Superficial fungal infections are common skin diseases, affecting millions of people worldwide [1]. Cutaneous and subcutaneous fungal infections can be caused by dermatophytes, yeasts and non-dermatophytes molds, although dermatophytes cause most of the cutaneous fungal infections. The dermatophytes are a group of closely related fungi that have the capacity to invade the keratinized tissue (skin, hair and nails) of humans and other animals to produce an infection, dermatophytosis and keratinomycosis commonly referred to as ringworm [2]. Infections are generally restricted to the skin and they do not penetrate the deeper tissue or organs of immunocompetent hosts [3].

This study has been undertaken with a view to see the superficial mycotic infection and the occurrence of the most prevalent fungi causing dermatophytosis in Surguja, Chhattisgarh.

\section{Methods}

For processing and identification of the fungi, following materials and methods have been used:

The present investigation, at about 187 samples from clinically suspected fungal infections especially dermatophytosis of various body sites including trunk, groin, head and scalp, face, hand, toe and finger, nails collected from local district hospitals. The sites of lesion were thoroughly cleaned with $70 \%$ alcohol. The samples were collected in a sterile screw caped tube by scraping across the inflamed margin of the lesions with the help of a disposable scalpel blade. Then samples brought to laboratory and stored on $37^{\circ} \mathrm{C}$ in an incubator for further studies.

\section{Identification}

\section{Microscopic analysis}

A small quantity of the material or sample (skin, nail, hair) was placed in a drop of $10 \% \mathrm{KOH}$ solution on a microscopic slide and a coverslip was placed over it. Then the slide was gently heat up over the flame to bring about clearing and the preparation was left inside a Petri dish for 20 minutes or more if the specimen was very thick. Then the slide was examined under the microscope for the presence of fungal elements.

\section{Culture medium}

The specimens were cultured in SDA (Saubroud Dextrose Agar) medium with chloramphenicol $(0.05 \mathrm{mg} / \mathrm{ml})$ and cyclohexamide $(0.5 \mathrm{mg} / \mathrm{ml})$. Sample were spread over the surface of the medium of prepoured Petri plates and then Cultures were incubated at $37^{\circ} \mathrm{C}$ for up to 7 days and checked at frequent intervals for growth. When growth of fungal colonies appeared, fungal species were identified on the basis of cultural characteristics, pigment production and microscopic examination in lacto phenol cotton blue preparation. Non-dermatophyte moulds were identified by microscopic morphology (Graser, 2006). Then identification were confirmed from Agharkar Research Institute Pune, India

\section{Result \& Discussion}

In the direct microscopic examination, the fungal elements seen in superficial mycoses were the septate branching hyphae of dermatophytes and the pseudohyphae and blastospores of Candida.

Table 1: Dermatophytes isolated from 64 cases of superficial mycotic infections

\begin{tabular}{|c|c|c|}
\hline Dermatophytes & No. of Isolates & $\%$ \\
\hline Trichophyton rubrum & 18 & 28.1 \\
\hline Trichophyton mentagrophytes & 06 & 09.3 \\
\hline Trichophyton tonsurans & 03 & 04.7 \\
\hline Trichophyton violaceum & 2 & 3.1 \\
\hline Total & $\mathbf{2 9}$ & $\mathbf{4 5 . 3}$ \\
\hline
\end{tabular}

Among the 64 cases, dermatophytes were the most prevalent and isolated from 29 cases $(45.3 \%)$ as shown in Table-1. Out of which the most frequently isolated were Trichophyton rubrum and T. mentagrophytes and reported in 18 cases $(28.1 \%)$ and 6 cases $(9.3 \%)$ respectively. Most studies also found $T$. rubrum and $T$. mentagrophytes as the commonest etiological agents of dermatomycosis in Udaipur region [5]. The other dermatophytes included $T$. tonsurans 


\section{International Journal of Science and Research (IJSR) \\ ISSN (Online): 2319-7064}

Index Copernicus Value (2013): 6.14 | Impact Factor (2014): 5.611

isolated from 3 cases (4.7\%) and T. violaceum from 2 cases $(3.1 \%)$.

Candida species were reported in 22 cases (34.3\%) and were more likely to be isolated from finger-nail infections. Nondermatophyte moulds accounted for $20.3 \%$ and reported in 13 cases, with Aspergillus species being the most common pathogen.

In our study, most of the infections due to T. rubrum were found in adults, which was consistent with the observations of Desai and Bhat [6] and $\mathrm{Ng}$ et al. [7] Candida species have high incidence in finger onychomycosis and T. rubrum has a relatively low incidence.

\section{Conclusion}

The men and women, especially those are working as agricultural laborers and taking part in showing rice on field, are commonly suffering with these problems. Because of they are continuing in crop field, where moist and muddy soil along with fungal spore may cause harm to their skin and through the skin pathogen can easily invade dermis and cause infection. 0n other hand, the people drink river water that contained large number of parasites and warms. These parasites and warms carry fungal spores, May cause infection.

\section{References}

[1] Deshmukh, S.K. (2002). Incidence of keratinophilic fungi from selected soils of Kerala state (India). Mycopathologia. 156:117-181.

[2] Deshmukh, S.K., Shukla, R.V.(2000).Isolation of keratinophilic fungi from poultry farm soils of Chhattisgarh (India). Kavaka, Vol.28 Issue 9:55-58.

[3] Garg, A.K. (1966). Isolation of dermatophytes and other keratinophilic fungi from soils in India. Sabouraudia. Vol. 4 pp 259-264.

[4] Graser, Y., De Hoog, S. and Summerbell, R.C. (2006).Dermatophytes: recognizing species of clonal fungi. Journal of Medical Mycology, 44(3):199-209.

[5] Jain,N., Sharma,M.(2011).Distribution of dermatophytes and other related fungi in Jaipur city, with particular reference to soil $\mathrm{pH}$. Mycoses.54:52-58.

[6] Kanbe, T. (2008).Molecular approaches in the diagnosis of dermatophytosis. Mycopathologia. 166(5-6):307-317.

[7] Pierard GE, Arrese JE, Pierard-Franchimont C. Treatment and prophylaxis of tinea infections. Drugs 1996; 52:209-24.

[8] Kalra SL., Mohapatra LN. Etiology of dermatophytosis in Delhi. lnd J Med Res 1964;52:553-558.

[9] Verma BS. Vaishnav VP, Bhatt R.P. A study of dermatomycosis. Indian J Dermatol Venereol. 1970;36:182-184.

[10] Conant NF, Smith DT, Baker RD, Coloway J L. Manual of clinical Mycology, $3^{\text {rd }}$ edition, W.B. Saunders Co, 1971;527-631.

[11] Murdia P. Dermatomycosis in Udaipur region. Indian Journal of Dermatology 1987; 32: 5-10.

[12]Desai SC, Bhat M. Dermatomycoses in Bombay. A study on incidence, clinical features incriminating species of dermatophytes and their epidemically. Indian J Med 1961; 49:662-71.

[13] Ng KP, Soo-Hoo TS, Na SL, Ang LS. Dermatophytes isolated from patients in University Hospital. Kuala Lumpur, Malaysia. Mycopathologia 2002; 155:203-6.

[14] Shukla, A.K. (2014a) Biodiversity in Aspergillus nidulans group on the basis of lipases profile. IJSR, ISSN: 2319-7064, Volume-3, Issue-6, pp1391-1394. (Impact factor- 3.358)Paper ID-02014487

[15] Shukla, A.K. (2014d) Occurrence of keratinophilic fungi from the soils of Chhattisgarh. ISSN: 2319-7064, Volume-3, Issue-9, pp 2041-2044. (Impact factor3.358) Paper ID- SEP14574

[16] Shukla, A.K. and Chouhan, S. (2011).Contamination of dermatophytes in soils of district Surguja, Chhattisgarh (India).Research Zone. Vol. 3:38-40.

\section{Author Profile}

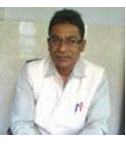

Dr. Ashok K. Shukla did M. Sc. Ph.D. (Microbiology). He is serving as Assistant Professor (Microbiology), Dept. of Microbiology \& Biotechnology, HCW College Ambikapur Chhattisgarh, India. He has published more than fifty research papers, review articles and two books. His Specializations include Biodeterioration and Degradation of various compounds, Medical microbiology, Dermatophytes, Mycotoxins \& Micotoxicoces 